\title{
English Societal Laws as the Origins of the Comprehensive Slave Laws of the British West Indies
}

\author{
JUSTINE COLLINS
}

\section{Introduction}

British West Indian colonial slavery was unparalleled in the speed at which it became essential to the workings of society; it became the 'essence of British Caribbean history'. ${ }^{1}$ Between the years of 1665 and 1833 the slave population in the West Indies increased rapidly. ${ }^{2}$ In Barbados, for example, there were 18,600 white colonists and 6,400 African slaves in 1643. By 1724, these numbers had changed dramatically: there were 18,300 whites and 55,206 African slaves. ${ }^{3}$ The slave population in the British West Indies amounted to approximately 775,000 in 1807 and had decreased by just 100,000 by 1834 (the formal end of the slave trade). ${ }^{4}$ The region owns the dubious distinction of being the first in the Americas to give rise to the sugar revolution, which in turn rested on slavery and helped to promulgate American colonial slavery. Caribbean slavery was distinctive, in that nowhere did the influence of the unholy trinity of slavery, sugarcane and the plantation system make itself more systematically and intensely felt. ${ }^{5}$ The colonial government and planter class, extremely aware and anxious of their minority position,

${ }^{1}$ B. L. Solow, Slavery and the Rise of the Atlantic System (Cambridge, 1991), 21-22. I will use the terms the Caribbean and the West Indies interchangeably.

2 B. Dyde, R. Greenwood and S. Hamber, Emancipation to Emigration, 3rd edn (New York, 2008), 33.

3 http://discoveringbristol.org.uk/slavery/routes/places-involved/west-indies/plantation-system/.

${ }^{4}$ B. W. Higman, 'Population and Labour in the British Caribbean in the Early Nineteenth Century', in Stanley L. Engerman and Robert E. Gallman (eds.), Long-Term Factors in American Economic Growth (Chicago, IL, 1986), 605-39.

${ }^{5}$ W. D. Jordan, White Over Black: American Attitudes towards the Negro 1550-1812 (Chapel Hill, NC, 1968), 3-4. 
ensured that they remained dominant through institutional implementation of policies and legislation covering the legal and economic aspects of slavery. The slave regime and the laws that sustained it connected the disparate colonies of the Atlantic world and provided the justification for the coerced migration of millions. ${ }^{6}$

West Indian colonial enslavement involved three interrelated aspects of law that were transformed with the introduction of African chattel slavery: firstly, defining slaves as property; secondly, establishing forms of control over slaves; and thirdly, developing legal definitions of race, which distinguished the African enslaved and their descendants from the rest of the population. ${ }^{7}$ This essay examines the origins of the comprehensive slave codes and slave treatment within the British West Indies. It delves into pre-colonial English society to identify various laws and regulations adopted and adapted in the colonies. It argues that transplantation was central to development within colonial legislation. This stands not just for the legal transplants from England to the colonies but within and throughout the colonies themselves. The transplants came in particular forms of property law, laws of villeinage, police law, martial law and various vagrancy regulations.

This essay contributes to the extant scholarship by Edward Rugemer, ${ }^{8}$ Christopher Tomlins ${ }^{9}$ and David Barry Gaspar ${ }^{10}$ on colonial West Indian plantation societies, their fallout and their legacies, by tracing their legal origins and legal ramifications. Furthermore, the research follows on from and adds to such North American scholarship by signifying the legal foundations of the slavery regime and its Atlantic connectivity. It provides a comprehensive analysis of the origins debate, specifically the importance of the Barbadian Code as the progenitor of legislating colonial enslavement, a feat not yet completely tackled within Caribbean legal history. Its claim is not that the English were innovators but rather

${ }^{6}$ S. E. Hadden, The Fragmented Laws of Slavery in the Colonial and Revolutionary Era (Cambridge, 2008), 253.

7 A. L. Hartfield, Atlantic Virginia Intercontinental Relations in the Seventeenth Century (Philadelphia, PA, 2004), 155.

${ }^{8}$ E. Rugemer, Slave Law and the Politics of Resistance in the Early Atlantic World (Cambridge, MA, 2018).

9 C. Tomlins, 'Transplants and Timing: Passages in the Creation of an Anglo-American Law of Slavery', Theoretical Inquiries in Law, 10(2) (2009), 389-421.

10 D. B. Gaspar, 'Rigid and Inclement: Origins of Jamaican Slave Laws of the Seventeenth Century', in C. Tomlins and B. H. Mann (eds.), The Many Legalities of Early America (Chapel Hill, NC, 2001), 78-96. 
improvisers within a region that was already conducive for their colonising tactics. ${ }^{11}$ The English were latecomers to the West Indies in comparison with their European counterparts, and in many ways these other powers provided a blueprint on how to create a successful slavery regime. The essay begins, though, with an examination of a particular piece of Caribbean slave legislation.

\section{The Barbados Slave Code, 1661}

Barbados will be my main point of reference. It was the richest settler island for the majority of the seventeenth and eighteenth centuries. The need for the development of comprehensive slave legislation was in a large part due to the success of the cash crop sugar. The growing demand for the crop necessitated the increase in importation of African slaves, requiring a proper mechanism for their regulation; by the 1650s, large, capital-intensive sugar plantations dependent on imported slave labour dominated Barbados. ${ }^{12}$ Following years of unrest, resistance from slaves and problems with indentured servants, the Barbados legislature decided it was time to attend to these issues.

In 1661, the Barbadian Assembly passed the first comprehensive slave code in the English Americas, to 'better manage its profitable but unruly slave society'. The Act was entitled 'An Act for the better ordering and governing of Negroes'. ${ }^{13}$ The code consisted of provisions that dealt with issues concerning order and governance of 'Negro slaves', since their 'heathenish, brutish and volatile proud manner' rendered prior laws unsuitable. The colonial Assembly acknowledged that although they had to enact laws which conformed to the laws of England, those English laws gave 'noe track to guide ... where to walk nor any rule set up how to govern Slaves'. ${ }^{14}$ Therefore, in light of this deficiency the

11 Throughout the essay I use the term 'English' as well as 'British'. 'English' refers to the time before the Union Act of 1707 which joined England with Scotland to form Great Britain. 'British' refers to the time after this.

12 R. B. Sheridan, Sugar and Slavery: An Economic History of the British West Indies, 1632-1775 (Kingston, 1994), 236; D. B. Gaspar, 'With a Rod of Iron: Barbados Slave Laws as a Model for Jamaica, South Carolina and Antigua', in D. C. Hine and J. McLeod (eds.), Crossing Boundaries: Comparative History of Black People in Diaspora (Bloomington and Indianapolis, IN, 2001), 343-66, at 343 and 344-5.

13 London, The National Archives (henceforth, TNA), CO 30/2, The Barbadian Comprehensive Slave Code, 1661 (henceforth, Barbados Slave Code, 1661).

14 Ibid., Preamble. 
Assembly decided to 'revive whatsoever wee have found necessary and usefull' in the former laws and to then create their own laws where English ones were lacking. ${ }^{15}$

The Act covered the four crucial issues concerning slaves: firstly, their growing numbers; secondly, their status as property; thirdly, their difference in culture; and lastly, their innate rebellious nature. The code's twenty-three articles covered a variety of issues pertaining to slave relations with the English colonials as a whole. Above all, it was concerned with all elements of slave control and coercion, including their criminal and non-criminal punishments. Of the twenty-three articles, approximately ten focused on prohibiting the mobility of slaves, whilst others also in some way tackled the potentiality of slave flights. The legislature thus created a superstructure of slave laws that consisted primarily of a precise criminal law of slavery, specifying categories of slave crime and appropriate trial and punishment. The Barbados Code gave masters and slaves demarcated rights and obligations; it left the masters with near complete dominion over the life and death of their slaves. Slave owners, overseers and even the layman-indentured servant were required to act as police officers, and in effect to manage slaves with a whip constantly in hand. The code did not address legal issues like purchase, sale, mortgaging or other financial transactions involving the enslaved; control, not commoditisation, was the legislators' paramount concern.

The Assembly also used the opportunity to address two other crucial issues. The first concerned the ambiguity over the status of indentured servants, linked to their treatment, and the second addressed the joint rebellions of those servants and slaves. The Servant Act and the Militia Act thereby came into fruition. ${ }^{16}$ These three Acts marked the deliberate attempt of the legislature to control and maintain the order of the underclasses: poor whites, vagabonds and the enslaved.

The Barbadian slave code was the 'premier slave code in the English colonies' by the early eighteenth century, due to its central role in initiating slave codes throughout the English slave-holding territories. ${ }^{17}$

15 Ibid.

${ }^{16}$ An Act for good governing of Servants and Ordeyneing the rights between Master and Servants; An Act for settling the Militia within this Island.

17 B. J. Nicholson, 'Legal Borrowing and the Origins of Slave Laws in the British Colonies', The American Journal of Legal History, 38(1) (1994), 38-54, at 41, 49 and 50. Barbados was indeed the 'seed crystal', as Christopher Tomlins put it, in inspiring the slave codes of other Caribbean slave holding colonies as well as North American colonies like South Carolina and Georgia; Tomlins, 'Transplants and Timing', 397. 
This codified legislation was an amalgamation of English property law, laws of villeinage, police law, ${ }^{18}$ martial law and various vagrancy regulations. It is important to examine these influences to decipher what exactly was adapted, borrowed or transplanted into colonial slave laws.

\section{English Property Law: Slaves as Chattels}

There was no initial codified treatment of slave status as chattels, although such a notion was embedded in the colonial custom and mind-set from the outset of colonial slavery. A variety of such rules, practices and attitudes, as we have seen, underlay the region's first comprehensive code. ${ }^{19}$ However, it was property law that lay at the core of English legal concepts and practices. It is therefore to be expected that the development of colonial organised societies would require protection specifically through property laws for newly acquired territories and peoples; one might 'assume that colonial Englishmen would apply English notions and rules of property to slaves. ${ }^{20}$ English property law provided a wide range of options and principles applicable to commoditising the enslaved. ${ }^{21}$

The institution of African slavery within the English Americas became dependent on ownership of humans as chattels. ${ }^{22}$ The Barbados Code's preamble stipulated that the enslaved would be protected as 'other goods and chattels'. ${ }^{23}$ A chattel under English property law was any property other than freehold. ${ }^{24}$ This legal concept was simple to make fit the instance of slaves, restricting any immediate need for colonial legislators to create statutes classifying slaves as property. Chattel property conceptions under English law conferred enormous power on the slave-owners. These included the right to destruction. ${ }^{25}$ As chattels, slaves could be

18 Police law was what is now known as criminal law, which can be defined as offences against the person, such as murder, rape or assault, or offences against property, such as theft or fraud; J. Holder, Principles of Criminal Law (Oxford, 2016), 1.

19 J. S. Handler, 'Custom and Law: The Status of Enslaved Africans in Seventeenth-Century Barbados', Slavery and Abolition, 37 (2016), 233-55, at 235. The English were accordingly conditioned with notions of race ideology and treatment from colonial enslavement progenitors, the Spanish and Portuguese.

20 T. D. Morris, Southern Slavery and the Law, 1619-1860 (Chapel Hill, NC, 1996), 42.

${ }^{21}$ Nicholson, 'Legal Borrowing' and Morris, Southern Slavery.

22 R. B. Campbell, The Laws of Slavery in Texas (Austin, TX, 2010), 2-4.

${ }^{23}$ Preamble, Barbados Slave Code, 1661.

${ }^{24}$ E. A. Martin and J. Law, Oxford Dictionary of Law, 6th ed. (Oxford, 2006), 31.

${ }^{25}$ Ibid., 745. 
used as mortgage, hired, sold up for debts, disposed of in accordance with inheritance laws, bequeathed, distributed in estate settlements, entailed and subject to a widow's right of dower; and they could be valued in currency or sugar, all while having no property rights themselves. ${ }^{26}$ Their chattel status remained for life, and passed on to their children (specifically through the matrilineal line), continuing as long as the institution existed. Furthermore, English personal property law included a doctrine of deemed ownership. ${ }^{27}$ Within colonial slavery persons had the legal right to punish slaves who did not belong to them but were found on their land. This meant that slaves were goods capable of giving relative titles to possessors. ${ }^{28}$

However, the Barbadian Assembly eventually defined slaves as real estate, though seven years after the 1661 Code. This meant that the heirs and widows of slave owners would not lose their property in slaves to creditors upon the owners' death: 'Two provisos made clear that slaves could still be bought and sold by the living, but the law protected a planter's investment in slaves as if they were a landed estate, to be preserved for his descendants. ${ }^{29}$

Claim to a property right, i.e. a legal right in a 'thing', was deemed as 'nothing but a permission to exercise certain natural powers, and upon certain conditions to obtain protection, restitution, or compensation by aid of public force. ${ }^{30}$ Slave-owners did what was necessary to preserve their property right in the enslaved. This usually involved seeking compensation for slave deaths or for dismemberment, as well as demanding the return of fugitive slaves, by offering rewards and threats. Issues did arise, however, when trying to interpret the law on slavery; for example, by trying and convicting the enslaved for various crimes, lawyers and judges inadvertently acknowledged their humanity. In addition, some saw owners as having the right to the slave services in addition to their obedience but did not purport to own the 'soul' of the slave. ${ }^{31}$

26 E. V. Goveia, The West Indian Slave Laws of the 18th Century (London, 2010), 20-21.

27 L. Rostill, 'Relative Title and Deemed Ownership in English Personal Property Law', Oxford Journal of Legal Studies, 35(1) (2015), 31-52.

${ }^{28}$ Barbados Slave Code, 1661, clause 1.

29 An Act declaring the Negro Slaves of this Island to be Real Estate in Acts of Assembly Passed in the Island of Barbados (London, 1721), 62-63, as summarised in Goveia, The West Indian Slave Laws, 21-22.

30 Ibid., 61.

31 Ibid., 62. 


\section{The Role of Villeinage}

Jamaican planter and historian Edward Long spoke of the correlation between villeinage and colonial slavery legislation within colonial Jamaica:

The Negroe code of this island appears originally copied from the model in use at Barbadoes; and the legislature of this latter island, which was the first planted by the English, resorted to the English villeinage laws, from whence they undoubtedly transfused all that severity which characterizes them, and shews the abject slavery which the common people of England formerly laboured under. ${ }^{32}$

Long contended that the harshness and general nature of West Indian slavery laws undoubtedly came from villeinage laws, to which they bore 'so near an affinity'. ${ }^{33} \mathrm{He}$ believed that the first settlers to the island colonies brought with them the prejudices of the villeinage system so much that it transferred to governance of African enslaved labourers. Long did cite other regulations as sources of colonial slavery legislation; however, he highlighted villeinage as the cornerstone.

There exists a multitude of discussions concerning the role played by villeinage in constructing colonial slave law. The connection was raised in discussions of chattel slavery and in litigation, despite arguments that neither time nor place could connect slavery and villeinage. ${ }^{34}$ The central link between the two forms of bondage was the lack of liberty, followed closely by the tie to the land and forced labour. Villeins in medieval England were by law unfree and in theory subject to the will of their lord who governed them through various rents and exactions 'all of which are usually assumed to have impacted negatively on their economic wellbeing and by extension the efficiency of the agrarian economy at large. ${ }^{35}$ A distinction could be drawn between two types of villeins. Villeins regardant were annexed to the property of the lord, whilst villeins in gross were annexed to the person of the lord and so transferable by deed from one owner to another. ${ }^{36}$ Villeins regardant appeared to correspond with the argument related to the enslaved being real estate and attached

32 E. Long, The History of Jamaica (London, 1774), 493-4.

33 Ibid., 495.

${ }^{34}$ See below at 314-17.

${ }^{35}$ M. Bailey, 'Villeinage in England: A Regional Case Study c. 1250-c. 1349', Economic History Review, 62(2) (2009), 430-57, at 430.

${ }^{36}$ H. Cary, A Commentary on the Tenures of Littleton (London, 1828), 295. 
to the property of their owner, whereas villeins in gross were themselves sellable and therein correspond simply to chattels. ${ }^{37}$

Villeinage principles served as a model for colonial slavery for several reasons, making it very suitable as the basis for what Alan Watson has called the process of legal transplant. ${ }^{38}$ Villeinage was never officially abolished, and cases pertaining to it continued up until the start of English Atlantic settlement. It was the primary example of a form of servitude which cemented bondsmen and their labour to the land of their lord. Akin to slaves, villeins were saleable, were unaware of their futures and were subjected to beatings and punishments. Lord Chief Justice Sir Edward Coke held in reporting on Combes's Case that 'the lord may beat his villain for cause or without cause and the villain shall not have any remedy. ${ }^{39}$ However, there were also major differences. Female villeins, according to Coke, 'had an appeal of rape, in case the lord violated them by force'. ${ }^{40}$ Such protection was not given to the colonial slaves. Law also prohibited the maiming and killing of villeins, which differentiated their position from that of colonial slaves. ${ }^{41}$ This was because the law recognised villeins as 'the king's subjects' (unlike slaves) and protected them 'against atrocious injuries of the lord: for he might not kill, or maim his villein, though he might beat him with impunity'. ${ }^{42}$ The colonial enslaved could be beaten, mutilated and even killed without any judicial recourse. The only ramification was the owner's compensation for the loss of property, which the colonial treasury bore. ${ }^{43}$ There were also distinctions in that villeins had at least a limited capacity to acquire property, and the passing on of status regarding the enslaved was simpler than that regarding villeins: children of enslaved persons simply inherited the status of the mother, at least within the English colonised territories. By contrast, though generally children of villeins inherited the status of their parents, where the male parent was a free person, the child would also acquire that free status.

37 For Pearne v. Lisle, see Reports of Cases in the High Court of Chancery, ed. C. Ambler (London, 1795), 77.

38 A. Watson, Slave Law in the Americas (Athens, GA, 1989), 63-65.

39 Co. Litt. 52. A; 9 Co. Rep. 76.

40 Ibid.

${ }^{41}$ S. Peabody and K. Grinberg, Slavery, Freedom, and the Law in the Atlantic World (New York, 2007); P. Hyams, Kings, Lords and Peasants in Medieval England: The Common Law of Villeinage in the Twelfth and Thirteenth Centuries (Oxford, 1980), 234-6.

42 Peabody and Grinberg, Slavery, Freedom, and the Law, chapter 2.2.

43 Barbados Slave Code, 1661, clause 18. 
Blackstone regarded villeins to rank legally somewhere between indentured servants and unfree chattel slaves. Lords tied villeins to themselves for a specified number of days each year, and on those days they coerced them to do whatever labour was required. ${ }^{44} \mathrm{He}$ also agreed with his predecessors that slavery did not exist in England and the laws of master and servant therefore were not synonymous with those of slavery. Blackstone contended that the colonies of North America were not English settlements but instead conquests, so they were not governed by English Common law but by the royal prerogative. Hence, he believed that the law pertaining to slavery in England (predominantly case law) was distinct from the law on slavery in the colonies (predominantly statutory law).

In terms of colonial enslaved persons, it was only upon entering the realm of England that they could ascertain their status and resist actions seeking their recovery. Within the colonies there was not a court where an enslaved person could seek redress either regarding status or illtreatment. Actions of recovery of the enslaved in the colonies comprised of offers of rewards and/or fines for either aiding or precluding their return. Within England, actions of either trover or trespass were used where an enslaved fled the premises of their owner; trover was an action in Common law that would lie for recovery of damages for the wrongful taking and detaining of specific chattels in which the plaintiff had a property right. ${ }^{45}$

The case of Chamberline v. Harvey $(1697)^{46}$ was one of the first to examine the possibility of colonial slaves being analogous to these categories of villeins. It concerned an enslaved person brought to England from Barbados. In the words of William M. Wiecek:

The slave in question had been owned originally in Barbados, where a slave was legally a part of real estate, rather than a chattel. He had been brought to England and baptised there. Counsel seized on these circumstances to explore the law of slavery and to begin unravelling the implications of the imperial relation. ${ }^{47}$

44 Blackstone, Commentaries of the Laws of England, Book II, 92-93.

${ }^{45}$ W. M. Wiecek, 'Somerset: Lord Mansfield and the Legitimacy of Slavery in the AngloAmerican World', University of Chicago Law Review, 42(86) (1974), 86-146, at 89 n. 10, quoting J. Chitty Pleadings.

465 Mod. 182 (K.B. 1697).

${ }^{47}$ Wiecek, 'Somerset', 91. 
The plaintiff sought the recovery of his property, i.e. the enslaved, through the remedies of either trespass or trover. His counsels argued that colonial slavery was an extension of villeinage and therefore baptism should not deprive an owner of his property in the enslaved. Wiecek has succinctly summarised their arguments as follows:

\begin{abstract}
slavery could nonetheless exist there, legitimated by a quasi-contract under which the master derived 'power' over the slave in return for providing him with food and clothing ... The peculiar feature of Barbadian law making a slave realty, counsel insisted, made a Barbadian slave the legal equivalent of a villein regardant (a villein attached to the manor, as opposed to a villein in gross, who was attached to the person of his lord). A villein regardant had to be formally manumitted (freed) by his lord, and this slave had not been. Any manumission here would have to be implied or constructive; from the slave's having been brought either to England or having been baptised. ${ }^{48}$
\end{abstract}

The enslaved's counsels, on the other hand, argued that there was no connection between villeinage and slavery because villeins held more legal rights than colonial slaves. An enslaved person could not be a villein in gross because he was not at large but rather born of parents belonging to the plantation. They also contended that the enslaved could not be a villain regardant either, since such a category required that the plaintiff and his ancestors be seised of this 'negro and his ancestors time out of memory of man'. Moreover, the enslaved did not possess the hereditary aspect that the lord and villein had. This was because 'villeinage rested on an ancestral tie to the land shared by the lord and the villein from time out of memory of man'. Villeinage and slavery were distinct.

Sir John Holt in Chamberline rejected the precedent of the case Butts v. Penny (1677), which stated that enslaved people were recoverable through trover. ${ }^{49}$ Holt opined that neither trover nor an ordinary action in trespass were suitable for the recovery of an enslaved person. He proposed that the appropriate remedy was trespass per quod servitium amisit, 'an old declaration claiming loss of the services of a servant'. The differences between the available actions were highly specialised. Whereas an action in trover would equate the enslaved to a chattel, thus 'a thing so utterly unfree that it was vendible', an action in trespass per quod servitium amisit would liken the enslaved to a bound or apprenticed

48 Ibid., 91-92.

49 Butts v. Penny 2 Lev. 201, 83 Eng. Rep. 518 (K.B. 1677).

50 Wiecek, 'Somerset', 90-91. 
labourer, 'a slavish servant, a human being whose freedom was restricted but not annihilated'. ${ }^{51}$

Lord Hardwicke, in addressing the link between villeinage and colonial slavery in relation to actions of trover, stated in Pearne v. Lisle in 1749 that 'There were formerly villains or slaves in England, and those of two sorts, regardant and in gross; and although tenures are taken away, there are no laws that have destroyed servitude absolutely. ${ }^{52}$ Hardwicke's opinion concerned the adjudication of a debt owed for the rent of fourteen black slaves. The defendant entered a rental contract for the services of enslaved persons for a two-year period but refused to pay the fee or return the enslaved. The plaintiff brought an action for their recovery when the defendant threatened to take the enslaved with him to Antigua. Hardwicke's decision used the words of villein and slave interchangeably. As Dana Rabin has contended, Hardwicke's 'elision of villeinage and slavery sanctioned chattel slavery and recognised the legitimacy of colonial legislation pertaining to slavery in the metropole'. ${ }^{53}$

Further cases throughout the seventeenth and eighteenth centuries reveal differing assessments regarding the relationship between slavery and villeinage. Lord Chief Justice Holt, in the case of Smith v. Brown and Cooper (1706), held that one may be a villein in England but not a slave. This reasoning was rooted in the idea that slavery did not exist within England. ${ }^{54}$ However, just a couple of decades later, in 1729 , it was reported that Attorney General Philip Yorke (1690-1764) and Solicitor General Charles Talbot (1685-1737) took a different view. They contended that the presence of enslaved persons within England, in the words of Rabin, 'had no liberating effect and no impact on a master's rights to his property. ${ }^{55}$ When he became lord chancellor, Yorke (now the first earl of Hardwicke) pronounced in Pearne v. Lisle that a slave is as much property as any other thing..$^{56}$

Other arguments arose in the late eighteenth century in the landmark case of Somerset v. Stewart concerning slave status in England. ${ }^{57}$ The case

51 Ibid.

52 For Pearne v. Lisle, see Ambler, ed., Reports of Cases, 77.

53 D. Rabin, “'In a Country of Liberty?": Slavery, Villeinage and the Making of Whiteness in the Somerset Case (1772)', History Workshop Journal, 72 (2011), 5-29, at 17.

542 Salk. R, 666.

55 Rabin, 'In a Country of Liberty?', 11.

56 Pearne v. Lisle, in Ambler, ed., Reports of Cases, 75.

57 New York Historical Society, Sharp Papers, MS Transcript (1772), 107-8. 
concerned James Somerset, a Virginian slave of a Bostonian customs officer, Charles Stewart. Somerset was bought from his Virginia plantation by Stewart and commenced his servitude to his new master in Massachusetts. Stewart took Somerset to London with him in 1769 where he was supposed to remain for a limited time for business purposes. After two years in Stewart's custody, Somerset fled from his master. Stewart then arranged his recapture and placement on the ship of Captain Knowles, headed to Jamaica, where Somerset would be resold into slavery there. ${ }^{58}$ Thereby the issue arose regarding the status of slaves in a jurisdiction where slavery allegedly had no legal basis.

When news of Somerset's abduction reached three abolitionists Thomas Walkin, Elizabeth Cade and John Marlow - they successfully applied to Lord Mansfield for a writ of habeas corpus to Knowles the ship owner. Knowles was ordered to return Somerset so that his case could be heard before Lord Mansfield. Acording to William R. Cotter, 'Mansfield was not especially sympathetic to Somerset and in fact required him, even though he was the plaintiff, to produce sureties for his appearances in court. ${ }^{59}$ The abolitionist Granville Sharp heard of the case and encouraged leading barristers to appear on behalf of Somerset, pro bono.

Somerset's lawyers contended that villeinage was not a precedent for trans-Atlantic slavery. English barrister William Davy stated that villeinage was 'confined to complexion ... and to a particular quarter of the world'. He further argued that from as far back as 1640, judges in the Star Chamber ruled that 'England was too pure of air for slaves to breathe. ${ }^{60}$ Villeinage in England consisted of English people with ties of family, transmitted only through ancestry, whiteness and place. ${ }^{61}$ Granville Sharp and his co-counsels further argued that colonial enslavement could not operate within England and that villeinage no longer existed at the time of the case, and hence no new family could confess to such a status. Nevertheless, Sharp and his counsels did concede, as did Mansfield, that slavery contracts outside of England were still valid. ${ }^{62}$

58 Ibid.

59 W. R. Cotter, 'The Somerset Case and the Abolition of Slavery in England', The Historical Association, 79(255) (1994), 31-56, at 34.

${ }^{60}$ New York Historical Society, Sharp Papers, MS Transcript (1772), 43.

61 Ibid.

62 Ibid., 82, 92. 
The Somerset case promulgated the ideal that slavery had no place within eighteenth-century English society. It also held that Englishmen never tolerated the institution. Simply touching the soil of England made men free. However, if this principle had been generally accepted, cases such as Somerset would not have required such lengthy deliberations. The constant movements (of persons, goods, ideas, laws and more) due to the slave trade and the fact that a number of plantation owners resided in England or at least visited regularly meant that there was necessarily some form of connection between the laws regarding blacks in the colonies and blacks in England. Comparing villeinage and slavery thus also signified a different but related issue: the question of jurisdictional boundaries and the connection between colonial and metropolitan laws. Case law as guidelines were particularly murky, exacerbating the entangled bonds of centre and periphery. ${ }^{63}$

\section{Police Law, Vagrancy Law, and Martial Law}

In Watson's account of slave laws in the English Americas, he described slavery as not simply concerned with the relationship between planter and slave but between both parties and the plantation societies of which they were a part. ${ }^{64}$ To understand why slavery and its related laws became such a public domain and why police laws acted as the basis of such laws, one must look at public order in early modern England. In the words of Bradley J. Nicholson:

\footnotetext{
Ex-soldiers, rogues, 'sturdy beggars' and vagabonds were a preoccupation of the ruling elite. Such 'idlers' were anathema to the Tudor elitist concept of society, a chain of ruling authority reaching down from the King and Queen, to the father of the household, or the master. Everyone was supposed to be subsumed with this hierarchy. Bond labour, especially apprenticeship for long periods, was a salient feature of English life, for the lower classes. The hierarchical ideal ... was sought aggressively through a long line of legislation which developed a strict and often brutal police law outside common law for society's lower strata. ${ }^{65}$
}

The English colonials sought to regulate indentured servants and slaves in ways highly similar to those used for the unemployed and vagabonds in England. In fact, many of the rogues and vagabonds became colonial

\footnotetext{
${ }^{63}$ Rabin, 'In a Country of Liberty?', 5.

${ }^{64}$ Watson, Slave Law, 66.

${ }^{65}$ Nicholson, 'Legal Borrowing', 42.
} 
indentured servants. The colonial elite, i.e. the planter class and administrators, strove for 'good government' analogous to that of the metropole. In so desiring this, they made attempts to replicate English society in the colonies, requiring that each member of the lower class have a master responsible for them. Anyone who fell outside this standard became perilous to the order of that colonial society. Therefore, to maintain order, colonials adopted and adapted English police laws. ${ }^{66}$

The police law of slavery borrowed some of the English vagrancy laws and therefore resembled or appeared to authorise provisions therein. The English believed that if such people were not controlled there would be a spread of vagrancy or vagabondage, which was, in Nicholson's words, the most 'intractable of social problems'. ${ }^{67}$ The 1547 Vagrancy Act provided that vagabonds could be enslaved for two years and those vagabond slaves were allowed to be bought and sold. Additionally, vagabond children became 'apprentices', which was arguably another term for child labour and slavery. The Act further provided for the enslavement of those who did not submit to the authority of a master as punishment. This provision was applicable to the unemployed, the homeless and the ill. In addition, a master could 'cawse the said slave to worke by beating, cheyninge or otherwise in such worke and Labour how vyle so ever it be ${ }^{68}$ A master could also place iron rings on the neck and feet of the enslaved. Those who absconded faced lifelong enslavement. Despite the Act being repealed soon after, it provided an example of how coerced labour laws could be constructed and directed towards those idle and restless members of society needing control. The Act thus illustrated, in Thomas Morris's words, that the 'English were quite capable of conceptualizing human beings as slaves', once a strict perception on the status of slavery was not taken. ${ }^{69}$

The West Indian slavery legislation, pioneered by Barbados, followed this example. In the words of Gaspar:

The police laws of slavery in Barbados ... came to be composed of practices well known in England, and based on England's previous experience with problems of social order in the sixteenth century. The colonists found the sixteenth century experience valuable because the legal

66 Ibid.

67 Ibid.

68 The 1547 Vagrancy Act as quoted in C. S. L. Davies, 'Slavery and the Protector Somerset: The Vagrancy Act of 1547', Economic History Review, 2nd ser., 19 (1966), 533-49, at 534.

69 Morris, Southern Slavery, 42. 
dimension of slavery was foreshadowed by the problem of masterless men in England during the previous century. ${ }^{70}$

The Barbadian Code stipulated that a slave was to be 'severely whipped, his nose slit and bee burned in the face' if he ran away or misbehaved. ${ }^{71}$ Such a provision followed the English Act, which recommended the branding of vagabonds with the letter ' $R$ ' for various misdemeanours including absconding, thereby identifying and proclaiming status. $^{72}$

The laws of the metropole also paved the way for the requirement that slaves carry passes when they had to leave a plantation. ${ }^{73}$ Both servants and slaves alike had to carry passes whenever outside their plantation, even if only to do tasks required of them by their masters. The 1563 Statute of Artificers dictated that workers were to carry passes if leaving the master's service. Letters from the Privy Council in 1569 and 1571 and a Royal Proclamation in 1590 also endorsed the pass requirement for workers in England. ${ }^{74}$

Martial law, in the words of Albert Dicey, is essentially the 'suspension of ordinary law and the temporary government of a country or parts of it by military tribunals.$^{75}$ It was usually decreed either in a time of war or through acts of necessity in response to an immediate threat to peace. It was borne out of the courts of constables and marshals of the king's armies and via ambulatory courts by travelling marshals trying, convicting and executing those who were guilty of treason. ${ }^{76}$ The notion emerged during the period from about 1300 to 1628 , the epoch that marked, in J. V. Capua's words, the 'establishment of custom governing the situations in which it might be invoked'. ${ }^{77}$ Such law, the object of much controversy, ${ }^{78}$ was invoked by those who, as David Dyzenhaus has

${ }^{70}$ Gaspar, 'Rigid and Inclement', 87-88.

${ }^{71}$ Barbados Slave Code, 1661, clause 2.

721 Edw. Vic.3 (1547).

73 Barbados Slave Code, 1661, clause 1.

74 F. Aydellote, Elizabethan Rogues and Vagabonds (Oxford, 1913), 62, 64, 66.

75 A. V. Dicey, Introduction to the Study of the Law of the Constitution, 8th edn (New York, 1924), 283-4.

76 J. M. Collins, Martial Law and English Laws, c. 1500-c. 1700 (Cambridge, 2016), 44.

77 J. V. Capua, 'The Early History of Martial Law in England from the Fourteenth Century to the Petition of Right', Cambridge Law Journal, 36(1) (1977), 152-73, at 152.

78 D. Edwards, 'Beyond Reform: Martial Law and the Tudor Re-Conquest of Ireland', History Ireland, 5 (1997), 16-21; P. D. Halliday, Habeas Corpus: From England to Empire (Cambridge, MA, 2010), 68-69. 
noted, 'maintained the British Empire, as they sought to defend imperial interests in the midst of an often very hostile local population. ${ }^{79}$ This situation obviously was applicable to the slave holding territories of the West Indies.

Martial law justice was akin to the summary proceedings applicable to the adjudication of slave trials, where such proceedings became the norm in tribunals set up particularly for such matters and separate from the common-law courts. The Barbadian Code prescribed that less than a full English jury of peers should try the enslaved who were accused of crimes. ${ }^{80}$ This clause also imitated the Statute of Artificers, mentioned above, which laid down that slaves be tried by two justices of the peace or a town mayor and 'two others of the discreetest persons' of the relevant town. $^{81}$

Reports likened Jamaica to a great garrison or army, and it was the only island colony that utilised martial law prior to the plantation economic boom. The Jamaican judiciary adapted English legal discourses to widen the range of martial law. Threats, conspiracies or rumours of attacks, rebellions and invasions were frequent around the period that England took Jamaica from the Spanish. Soldiers and sailors who failed to conform to English law during times of war were disciplined using martial law. The governor and the council of war then used their discretionary power in the aftermath of their battle with the Spanish to institute martial law. They thought this necessary to curb not just threats from the Spanish but also privateers, buccaneers and pirates. However, Charles II decided in 1661 to limit the powers of the Governor via a Crown order. This allowed the establishment of an elected council and civilian courts to carry out justice based upon a non-repugnancy principle' ${ }^{82}$

The slavery legislation of Barbados prescribed martial law in the event of any slave rebellion or uprisings. Clause 17 of the 1661 Code indicated that such are acts of insurrection or rebellion: to make preparation of arms, or offensive weapons, or hold any council or conspiracy for raising mutinies or rebellion in the island 'are

79 D. Dyzenhaus, 'The Puzzle of Martial Law', University of Toronto Journal, 59 (2009), $1-64$, at 2.

80 Barbados Slave Code, 1661, clause 13. Clauses 14 and 16 also repeat how slave trials were to be carried out.

${ }^{81}$ For Statute of Artificers, see 5 Eliz. C.4 (1562-63).

82 TNA, CO 1/15, fo. 20, as summarised in Collins, Martial Law and English Laws, 228-9. 
immediately grounds for the enactment of martial law with the punishment of death or other pains as their crimes deserve'. Still fearful of its vulnerability for attacks, being so far removed from other English colonies, Jamaica enacted a Militia Act in 1664 along with their Slave Code. This Act was justified on the basis that the island was in the 'midst of a subtile, rich and potent enemy', referring to the fugitive slaves and eventually the Maroon community. ${ }^{83}$ The Act was used in the next year to quell insurrections by the slave and fugitive slave populace. Martial law provisions became part of the Jamaican slavery regime, which was marked by constant slave uprisings and absconding. Beyond Jamaica, martial law was not as popular during the peak of plantation society, apart from the summary judgment proceedings aforementioned. The only occasions that warranted martial law's use in other islands were much later: the Demerara and the Barbados 'Bussa' slave rebellions quashed in the 1810s and 1820 s.

\section{Conclusion}

At the core of slavery regulatory mechanisms within the English West Indies was the need to control the ever-growing population by the minority governing power. The foundations of West Indian slave legislation are plentiful yet diverse. To have a full understanding of the contribution of each to the slave codes is near impossible. However, the objective of identifying the underpinnings of the slave codes is to illustrate how transplanted elements of law operated in a system not mirrored or extant in England. Those composing legislation were able to improvise, using these useful foundations as a framework to establish a comprehensive code that had no match in the metropole. Slavery was not legal in England, so legislators in the West Indies looked to a concept that resonated near enough to such a system of bondage, hence the relevance of villeinage. However, this connection created a plethora of never fully reconciled issues concerning the link between villeins and colonial slaves, the status of villeins, and the issue of villeins being chattels and thus synonymous to slaves. Further, English societal regulations concerning

${ }^{83}$ TNA, CO 139/1, The Jamaica Militia Act, 1664, 49-51. The fugitive slaves were those left behind from Spanish colonisation of the island who eventually united with those slaves brought by the English to Jamaica to form Maroon fugitive communities. 
vagabonds, police laws pertaining to criminal activities and antirevolutionary laws encompassed within martial law all provided the backbone to the structure of the code. That slavery lasted for over two centuries indicates that these adapted provisions were mostly successful and suited to the maintenance of the slavery regime. 